\title{
The Influence of Profitability and Financial Leverage on Dividend Policy: An Evidence from Manufacturing Industrial Companies in Indonesia
}

\author{
I Gede Adiputra $^{1 *}$
}

\author{
${ }^{1}$ Faculty of Economics and Business, Universitas Tarumanagara, Jakarta, Indonesia \\ *Corresponding author. Email: gedea@fe.untar.ac.id
}

\begin{abstract}
The purpose of this study is to determine the effect of profitability and financial leverage on dividend policy in manufacturing industrial companies listed on the Indonesia Stock Exchange from 2015-2019. The sample in this study is 18 manufacturing companies selected by purposive sampling method. The company data for sample selection is taken from the Indonesia Stock Exchange official website, which is idx.co.id. The analysis technique used in this study is panel data regression analysis, assisted by software Econometrics Views (EViews) version 11. The results indicate that profitability does not have a significant effect on dividend policy, while financial leverage has a significant and positive effect on dividend policy.
\end{abstract}

\section{Keywords: Profitability, Financial Leverage, Dividend policy}

\section{BACKGROUND}

It has been the goal of company to maximize the value of the company where the value of the company can be used as the measurement to assess the success of the company which is usually associated with the company's stock price on the stock exchange. The manufacturing industry is an important sector in the economy that is essential for developing the economy in Indonesia. A company's sustainability can be measured by the value of the shares. The value of the shares is measured based on the current earnings and the potential of the company to grow. Manufacturing industrial companies develop in various sectors. The growth and performance of manufacturing industrial companies can be influenced by funding and profits.

High value of a company can attract investors to invest and increase the investors' trust towards the company's performance and future prospects. For an investor, the purpose of buying shares in a company can be to obtain capital gains and dividends. Capital gain or loss is an increase or decrease in the price of a share and because of this, investor can get profit or loss, while dividends are the distribution of profits to the shareholders of the company, whereas the amount of dividends that each shareholder will earn is based on the proportion of their shares [1]. In general, dividends are the investor's right to get part of the company's profits. However, some companies that have gone public do not fulfill the rights of these investors. According to [2], equity shareholders have a right to a dividend form the profits of the company, but only if a dividend is declared by the board of directors. It can be concluded that shareholders can get the rights in the form of dividends, but the dividend distribution is decided and approved by the board of directors because there are many aspects of financial considerations and profits that happen in the company in a certain period.

Profitability is one of the factors that the board of directors considers in making dividend distribution decisions. A company's profitability represents its ability on generating profits and the measurement of management efficiency in a company. The company's profitability can be measured on the Return on Assets (ROA).

The level of debt or leverage is one of the factors that affect dividend distribution policy. The higher the debt, the more company decides to keep the profits in order to pay for the debt. That is why companies with a high amount of debt prefer to pay dividends in small amounts. Because of this, long-term and short-term debt can affect the level of dividends that must be paid. This is why many go public companies pay dividends not constantly but fluctuating. Several previous studies have shown different results, research from [3], [4] shows that the profitability is significant towards dividend policy, while different results are shown by [5], [6] in the study found that Profitability was not significant to the dividend policy. Likewise, research from [3], [7] which shows that Financial Leverage (DER) significantly affect Dividend Policy (DPR), while [5], [4], [8] show that Financial Leverage (DER) has a significant effect on Dividend Policy (DPR). Based on those problems, this study is aimed to prove that profitability and financial leverage have effect on dividend policy in manufacturing industrial companies listed on the 
Indonesia Stock Exchange (IDX) for the 2015-2019 periods.

\section{LITERATURE STUDY}

\subsection{Agency Theory}

The Agency theory explains a relationship between agents and principals. [9] defined agency relationship as a contract between the owner (principal) and the manager (agent) to carry out a task preferred by the principal by delegating decision-making authority to the agent. According to [9], agency theory aims to explain how to minimize costs due to asymmetry information and uncertainty conditions. Agency theory describes the separation of company's rights with the responsibility for decision making. The relationship between the agent and the owner tends to cause conflicts between the two parties because of different interest and mindsets.

\subsection{Signaling Theory}

According to Richard D. Morris (1987) in [10], signaling theory is developed to deal with asymmetry information problem in companies by giving more signal of information from parties who have more information to uninformed stakeholders. Signaling theory shows that whatever information obtained from the condition of the company's shares, it will always influence investors' decision making. The company encourages the provision of information because of the asymmetry information between the company and external parties. This can be happened because the company knows more about the internal condition and the future prospects than external parties such as investors and creditors.

\subsection{Dividend Policy}

Every company that uses the capital, for example in financing the issuance of shares that are sold to the general public, requires to distribute dividends to the shareholders as stated by [2]. [2] states that shareholders can obtain their rights in the form of dividends but dividend distribution is inseparable from the company's performance in generating profits and also depends on the company's capital structure. Dividend policy has always been an essential policy in corporate finance because the goal of a company is to grow and survive in the midst of intense competition. That is why the company must be able to manage profits whether the profit is distributed in the form of dividends or retained. [11] develop the "catering dividend theory" which holds that investors are placing a higher stock prices in companies that pay dividends rather than companies that do not pay dividends. Companies do this to maximize the value of the equity market. According to [12], the amount of dividends paid by the company to the shareholders depending on the company policy.

\subsection{Profitability}

According to [13], Profitability is a net profit that can be achieved by a company during the company's operations. Profitability ratios include Cash Return on Assets, Return on Equity, Return on Assets, Cash Flow Margin, Net Profit Margin, Operating Profit Margin, and Gross Profit Margin, but in practice some experts more often emphasize this profitability measure on Return on Assets in measuring company performance in generating profit. According to [14], Return on Asset is a ratio which measures the overall effectiveness of management in generating profits with its available assets. From the definition above, ROA plays an important role in the ratio analysis because it is the ratio of net tax returns which is also a measurement to determine the return on company's assets [15]. When compared with similar companies or compared with the data in the previous period, a high rate of Return on Assets will show good performance related to the company's profitability. This ratio shows how effectively management of using its assets, both current and fixed assets, to get income. A company's ability on earning profits is the main indicator to pay dividends. That is why profitability is the most important determinant of dividends [16]. Meanwhile, [17] state that the capital structure is the ratio of company's long-term debt with the company's capital.

Based on research done by [18], profitability (ROA) significantly affects dividend policy (Dividend Payout Ratio). The study of [5] showed that Return on Assets (ROA) has a negative and insignificant effect on Dividend Payout Ratio (DPR). Research carried out by [7] showed that profitability significantly influences Dividend Payout Ratio (DPR). Research carried out by [3] showed that profitability significantly influences Dividend Payout Ratio (DPR).

Research carried out by [6] attempted to determine the impact of stock price, ROA, and the Company's Dividend Payout Ratio. The results implied that ROA significantly and positively impact dividend policy.

From these studies we can conclude that a company's dividend policy can be influenced by its net profit generated for profitability have an important role in determining the dividend to be distributed by the company, while the level of corporate funding needs doesn't have any impact on dividend policy.

Based on the description above, the first hypothesis is:

$\mathrm{H}_{1}$ : Profitability is a positive predictor of dividend policy.

\subsection{Financial Leverage}

To fulfill the company's financial needs, the company's capital and retained earnings can be used. If there is still a deficit in corporate financing from the equity, then usually company will consider about debt (leverage). Generally, the term "leverage" describes a the ability of a company to 
operate funds or assets with constant expenditures to increase the the company's income. Funds or cash are very important for a company to carry out daily activities which are used to generate profits for the company. The larger the company scale, the higher fund is required. This funding can be obtained through long-term debt and current debt or often referred to as debt financing.

According to [19], long-term debt is debt repaid in more than one accounting period, while current debt is an obligation that must be paid / repaid within one year. Besides debt, funding can be obtained from equity (equity financing). According to [20], equity financing is financing that comes from own capital (individual companies or firms) or by issuing equity letters, which is shares (corporate companies). According to [21] "Liabilities are probable future sacrifices of economic benefits arising from the present obligations of a particular entity to transfer assets or provide services to other entities in the future as a result of past transactions or events."

From research conducted by [3], this shows that financial leverage (Debt-to-Equity Ratio) significantly affect dividend policy (Dividend Payout Ratio). Furthermore, research conducted by [7] entitled 'The Effect of Profitability and Leverage on Dividend Policy' shows that leverage negatively and significantly affect dividend policy. Research conducted by [3] entitled implied that leverage doesn't significantly affect Dividend Policy. Another research by [4], as well as another researcher conducted by [8] showed that Debt-to-Equity doesn't have any effect on dividend policy (Dividend Payout Ratio).

Based on the description above, the second hypothesis is:

$\mathrm{H}_{2}$ : Financial Leverage is a negative predictor of dividend policy.

Based on researches conducted by several previous researchers, the following research model formulations can be shown as follows:

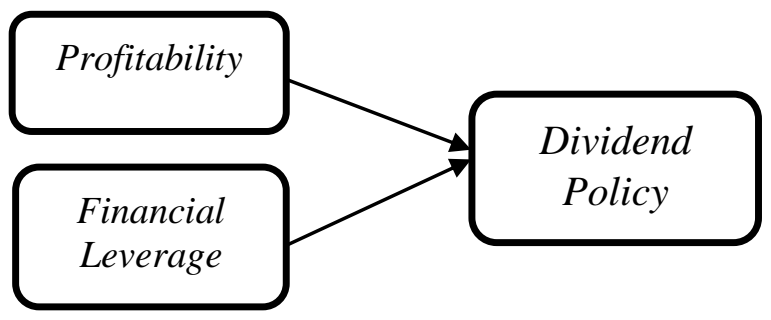

Figure 1. Research Model

\section{METHODOLOGY}

This study uses multiple linear regression analysis technique. The variables in this research are financial profitability and leverage. The population is manufacturing industrial companies listed on the Indonesia Stock Exchange (IDX) in the 2015-2019 periods. A purposive sampling is used with 18 samples of manufacturing industrial companies. The data collected is panel data which is a combination of cross section and time series data, which is secondary data from www.idx.co.id (Indonesia Stock Exchange) and the websites of each company. The sample criteria used to determine sample members are: a. The selected companies are consumer goods companies listed on the Indonesia Stock Exchange (IDX) for the 2015-2019 period. b. Companies that present complete data about the variables used in this study. c. Companies that present financial statements in rupiah currency. d. Companies that have never changed business sectors during the 2015-2019 period. e. Companies that pay dividends in determining the appropriate regression model, the author conducts two tests, which are the Chow test and the Lagrange Multiplier test. After finding the correct model, the author conducts multiple linear regression analysis to test the research hypothesis. In analyzing the data, the author uses Microsoft Excel 2007 and Econometrics Views (E-Views) version 11 software. Profitability is measured by Return on Assets (ROA), which shows the percentage of net income earned by the company:

$$
\text { Return on Asset }=\frac{\text { Net Income }}{\text { Total Asset }} \mathrm{x} 100
$$

Financial leverage can be measured by the Debt-to-Equity Ratio (DER). DER is the ratio of debt with equity.

$$
\text { Debt to Equity Ratio }=\frac{\text { Total Debt }}{\text { Total Equity }} \times 100
$$

Dividend Payout Ratio (DPR) is used to measure dividend policy. This ratio shows the percentage of each profit earned and distributed to shareholders in cash.

Dividend Payout Ratio $=\frac{\text { Dividend Per Share }}{\text { Earning Per Share }} \times 100$

\section{RESEARCH RESULTS}

The variables used in this study are profitability which is proxied through Return on Assets (ROA), financial leverage is proxied by Debt-to-Equity Ratio (DER) and dividend policy which in this case will be measured by DPR. Table 1 illustrates the result of multiple linear regression analysis via common Effect Model. 
Table 1 Multiple Linear Regression with Common Effect Model

\begin{tabular}{|l|l|l|l|l|}
\hline Variable & Coefficient & Std. Error & $\begin{array}{l}\text { t- } \\
\text { Statistic }\end{array}$ & Prob. \\
\hline C & 26.47398 & 1.85674 & 3.85674 & $0.0073^{*}$ \\
\hline ROA & 2.74563 & 4.39876 & 1.36502 & $0.1381^{*}$ \\
\hline DER & -0.842958 & 0.26478 & -3.28768 & $0.0407^{*}$ \\
\hline R-squared & 0.473947 & & & \\
\hline $\begin{array}{l}\text { Adjusted } \\
\text { R-squared }\end{array}$ & 0.448526 & & & \\
\hline F Statistic & & & & \\
\hline
\end{tabular}

Note: *significance $5 \%, * *$ significance $10 \%$

Source: EViews version 11 data processing result

Based on the data from Table 1, the regression equation is constructed as follows:

DPR $=26.47398+2.74563$ ROA -0.842958 DER

whereas:

DPR = Dividend policy of manufacturing industrial companies listed on the IDX in the 2015-2019 periods.

ROA = Profitability of manufacturing industrial companies listed on the IDX in the 2015 - 2019 periods.

DER = Financial leverage of manufacturing industry companies listed on the IDX in the 2015 - 2019 periods.

The probability value (p-value) of the profitability variable (ROA) is 0.1381 , which is more than 0.05 . This means that the profitability (ROA) doesn't have any significant impact on dividend policy (DPR) of manufacturing industrial companies listed on the IDX in the 2015-2019 periods. The p-value of the financial leverage is 0.0407 where the number is less than 0.05 . This means that financial leverage (DER) significantly affect dividend policy (DPR) of manufacturing companies listed on the IDX for the 2015-2019 period. The results of F statistical test resulted in F-statistic value of 18.572869 with the significance of the regression model is 0.000000 . This value is smaller than the significance level of 0.05 . This means that profitability together with financial leverage have a significant effect on dividend policy.

\section{DISCUSSION}

Profitability doesn't significantly affect dividend policy in manufacturing industrial companies listed on the IDX for the 2015-2019 periods. This study found that the scale of the dividends distributed to shareholders has nothing to do with the level of profitability. This can be happened because of the increase in sales is not always accompanied by profits gained. There are still several cost elements in sales that will reduce the amount of profit earned, for example cost of goods sold, business costs, tax costs, subsidies to pay dividends to shareholders and profitsharing costs. The amount of this cost is one of the causes of profit instability which can affect company profits. This research is in line with research conducted by [5], [6].
Meanwhile, this result is not in line with research conducted by [3], [4], and [8].

Financial leverage significantly and negatively affect dividend policy of manufacturing industrial companies in the 2015-2019 periods. The results of this study indicate that the higher DER level of the company, the lower level of dividend payments need to be paid to shareholders. The reason is, if debt increases, it will have an impact on shareholder's net income. The dividends distributed by company will decrease because the company's profits will be used to pay the obligations (debt). This research is in line with research conducted by [3], [7] which show that financial leverage (DER) has a significant effect on dividend policy (DPR). Meanwhile, this research is not in line with the study of [5], [4], and [8]

This research also shows that profitability together with financial leverage have significant effect on dividend policy. This is supported [22], [8], [4] and [3] who state that together, the variables of leverage and profitability significantly affect dividend policy. This means that there is a simultaneous influence of profitability and financial leverage on dividend policy.

\section{CONCLUSION AND SUGGESTION}

\subsection{CONCLUSION}

Based on the analysis and discussion that has been done above, the authors can conclude that profitability does not significantly affect dividend policy of manufacturing companies listed on the IDX, while financial leverage has a negative and significant effect on dividend policy, and profitability and financial leverage which are measured together significantly affect dividend policy of manufacturing companies listed in the IDX for the 20152019 period.

\subsection{SUGGESTION}

Companies need to pay attention on operational efficiency which has a significant relationship to Return on Assets. Companies need to minimize company costs as efficiently as possible such as general and administrative costs, sales and distribution costs, financial costs, and other operational costs to increase sales. Companies are expected to pay attention on financial leverage, especially the Debt-to-Equity Ratio. There is no problem as long as the profit is greater than the debt. The amount of profit earned will have an impact on the welfare of shareholders.

\section{ACKNOWLEDGMENT}

This research was supported by Tarumanagara University where the author is a lecturer. We thank DR. Sawidji Widoatmodjo, SE, MM as Dean of the Faculty of Economics and Business, 
Tarumanagara University who provided insight and expertise that was very helpful in this research. We thank Mr. Ir. Jap Tji Beng, MMSI., PhD, head of the Institute for Research and Community Service, Universitas Tarumanagara, Jakarta. We also want to thank the organizers of International Conference on Economics, Business, Social, and Humanities (ICEBSH) for sharing their wisdom with us to attend the International Conference.

\section{REFERENCES}

[1] Usman, Sarah (2017). Perencanaan dalam keuangan perusahaan. Jakarta: Deepublish.

[2] Coyle, Brian (2002). Equity Finance. Italy: The Chartered Institute of Bankers.

[3] Kurniawan, E. S., Sukoco, A., \& Suyono, J. (2019). The Influence of Return on Assets, Return On Equity, Debt Equity Ratio on Dividend Policy of Pharmaceutical Companies Listed on the Indonesia Stock Exchange Period 2014-2017. International Journal of Integrated Education, Engineering and Business, 2(2), 87-94. https://doi.org/10. 29138/ijieeb. v2i2.956

[4] Wicaksono, S., \& Nasir, M. (2014). Faktor-Faktor yang Mempengaruhi Kebijakan Dividen Pada Perusahaan Manufaktur yang Terdaftar di BEI Periode Tahun 20112013. Diponegoro Journal of Accounting, 3(4), 1-13. http://eprints.undip.ac.id/44638/

[5] Atmoko, Y., Defung, F., \& Tricahyadinata, I. (2018). Pengaruh Return on Assets, Debt to Equity Ratio, dan Firm Size Terhadap Dividend Payout Ratio. KINERJA, 14(2), 103-109. https://doi.org/10.29264/ jkin.v14i2.2486

[6] Septiani, M., Ariyani, N., \& Ispriyahadi, H. (2020). The Effect of Stock Prices, Return on Assets, and Firm Size on Dividend Payout Ratio: Evidence from Indonesian Financial Service Companies. Diponegoro International Journal of Business, 3(1), 17-27.

[7] Christine, Debbie dan Syfa Fijriestari Suryono. 2017. Pengaruh Profitabilitas dan Leverage terhadap Kebijakan Dividen. Citated from: https://scholar.google.co.id/ citations? user=2tqHML8AAAAJ\&hl=en Diakses pada 20 April 2019

[8] Hanif, M., \& Bustamam, B. (2017). Pengaruh Debt-toEquity Ratio, Return on Asset, Firm Size, dan Earning Pe Share Terhadap Dividend Payout Ratio (Studi pada Perusahaan Manufaktur yang Terdaftar di Bursa Efek Indonesia Tahun 2011-2015). Jurnal Ilmiah Mahasiswa Ekonomi Akuntansi, 2(1), 73-81. https://doi. org/10.24964/ ja.v2i1.20

[9] Jensen, M., C., dan W. Meckling, 1976. "Theory of the firm: Managerial behavior, agency cost and ownership structure", Journal of Finance Economic 3:305- 360, Downloaded from: http://www.nhh.no/for/ courses/spring/ eco420/jensenmeckling-76.pdf

[10] Mediawati, E., \& Afiyana, I. F. (2018). Dewan Pengawas Syariah dan Pengungkapan Sukarela Pada Bank Umum Syariah di Indonesia. Jurnal Riset Akuntansi dan Keuangan, 6(2), 259-268. https://ejournal.upi.edu/index. php/JRAK/article/view/12787

[11] Baker, M., dan Wurgler, J. (2004a). A Catering Theory of Dividends. The Journal of Finance, 59(3), 1125-1165.

[12] Awat, Napa J. (1999). Manajemen Keuangan. Jakarta: Gramedia Pustaka Utama.

[13] Soliha, Euis. dan Taswan. 2002. Pengaruh Kebijakan Hutang Terhadap Nilai Perusahan Serta Beberapa Faktor Yang Memperngaruhinya. Jurnal Bisnis dan Ekonomi. Vol. 9, No. 2.

[14] Gitman, Lawrence. (2009). Principles of Manajerial Finance. United States: Pearson Addison Wesley.

[15] Ikhwal, Nuzul (2016). Analisis Roa dan Roe Terhadap Profitabilitas Bank di Bursa Efek Indonesia. Jurnal Lembaga Keuangan dan Perbankan, 1(2), 211-227. http://journal.febi.uinib.ac.id/index.php/almasraf/ article/view/57

[16] Firdaus, I., \& Sedias, S. R. B. (2017). Pengaruh Profitabilitas, Likuiditas dan Struktur Modal Terhadap Kebijakan Dividen. Jurnal Ilmiah Manajemen dan Bisnis, 3(3), 398-419. http://digilib.mercubuana.ac.id/manager/t! @ file_artikel_abstrak/Isi_Artikel_747597605699.pdf

[17] Agus Harjito, Martono. (2008). Manajemen Keuangan, Edisi 1. Yogyakarta: Ekonisia.

[18] A., \& Martono, S. U. (2014). Manajemen Keuangan. Edisi Kedua. Yogyakarta: Ekonosia.

[19] Wibowo, \& Abubakar, A. (2009). Akuntansi Keuangan Dasar 2. Edisi Ke-3 Jakarta: PT Grasindo.

[20] Hery (2015). Analisis Laporan Keuangan Pendekatan Rasio Keuangan, Yogyakarta: CAPS.

[21] Riahi-Belkaoui, A. (2004). Accounting Theory. Cengage Learning EMEA.

[22] Dwidarnita Parera. 2016. Pengaruh Net Proft Margin (NPM), Return on Asset (ROA) dan Debt to Equity Ratio (DER) terhadap Dividend Payout Ratio (DPR) pada perusahaan yang tercatat dalam indeks LQ45 di BEI periode 2009-2013. Fakultas ekonomi dan bisnis jurusan akuntansi Universitas Sam Ratulangi Manado. ISSN: 2303-1174 Jurnal Emba Vol.4 No.2 Juni 2016, Hal.538548. 